Visit us - www.researchjournal.co.in $\square$ DOI : 10.15740/HAS/IRJAES/8.1/104-111

International Research Journal of Agricultural Economics and Statistics

Volume 8 | Issue 1 | March, 2017 | 104-111 $\mathbf{a}$ e ISSN-2231-6434

\title{
Research Paper Wheat price movement across major markets of Madhya Pradesh
}

See end of the paper for authors' affiliations

Correspondence to : V.M. BODADE

Department of

Agricultural Economics and Statistics, Dr.

Panjabrao Deshmukh

Krishi Vidyapeeth, AKOLA

(M.S.) INDIA

Email : vijayraj139@

gmail.com

\section{Paper History :}

Received : 01.01.2017;

Revised : 26.01.2017;

Accepted : 05.02.2017
Abstract : This paper has examined the market integration of wheat in Madhya Pradesh. Both market arrivals and prices of wheat have depicted increasing trends in almost all the selected markets of Madhya Pradesh. The present study aimed to study price movement of Wheat i.e. seasonal variation, price volatility and co-integration among the major wheat markets in Madhya Pradesh. For study purpose the data related to monthly average prices and arrivals of Wheat were collected from major markets from different markets in States viz., Bhopal, Gwalior, Indore, and Ujjain for the period 20052016. Moving average method used to study seasonal variation. The econometric tools like ADF test, Johansen's multiple co-integration test, Granger Causality Test and ARCH-GARCH model were used to arrive at conclusion. The results of study showed that the prices of wheat were higher in the months from March to August in all selected markets. The cyclical variation observed in the prices of Wheat in the selected markets. For all selected markets the prices series are free from the consequences of unit root and were stationary at first difference. The selected markets show long run equilibrium relationship and co-integration between them. Most of the markets showed bidirectional influence on Wheat prices of each other. Bhopal, Gwalior, Indore and Ujjain recorded low price volatility in wheat prices.

KEY WoRDS : Wheat, Market integration, Seasonality, Co-integration

How To Cite This Paper : Bodade, V.M., Deshmukh, R.G. and Borkar, Prema (2017). Wheat price movement across major markets of Madhya Pradesh. Internat. Res. J. Agric. Eco. \& Stat., 8 (1) : 104-111, DOI : 10.15740/ HAS/IRJAES/8.1/104-111. 